\title{
Mette Volquartzen: Politi og privat vagtvirksomhed
}

Djøf Forlag 2020, (348 sider) ISBN 9788757446234.

Boken Politi og privat vagtvirksomhed er med mindre justeringer identisk med Volquartzens ph.d.-avhandling med samme tittel. Avhandlingen hadde undertittelen «Retlige perspektiver på opgavefordelingen mellem politiet og den private sikkerhedsbranche». Undertittelen er fjernet fra bokutgaven, men det er oppgavefordelingen mellom politiet og den private sikkerhetsbransjen som er bokens tema. Fokuset er på oppgavene med å opprettholde trygghet, sikkerhet, fred og orden i samfunnet. Volquartzen forsvarte den vitenskapelige kvaliteten på arbeidet ved Det Juridiske Fakultet, Københavns Universitet den 13. mai 2019. Jeg var ved den anledning opponent. Bedømmelseskomiteen var ikke i tvil om at teksten og det muntlige forsvaret tilfredsstilte kravene som gjelder for en ph.d.-avhandling innenfor rettsvitenskap. I denne sammenheng vurderes teksten med tanke på en større leserkrets og mer allmenne forventninger til en bok om forholdet mellom politiet og den private sikkerhetsbransjen.

Bokens formål er på s. 20 uttalt å være «at tilvejebringe kvalificeret viden på området så eventuelle fremtidige politiske beslutninger om, hvorvidt politiet kan samarbejde med eller udlicitere opgaver til privat vagtvirksomhet, kan blive truffet på et mere oplyst og objektivt grundlag». Det er en snever formålsangivelse. Boken kan med fordel leses som noe mer enn et vitenskapelig opplyst debattinnlegg, og av andre enn politikere, nettopp fordi den ikke er motivert av et politisk program om mer eller mindre privatisering av ordensmakt. Forfatteren er rettshistoriker og boken gir rettshistoriske, juridiske og mer generelle samfunnsanalytiske perspektiver på behovet for delegasjon av politimyndighet i moderne samfunn. Det er særlig de seneste tiårs diskusjoner om delegasjon av politimyndighet for å sikre sosial kontroll og sikkerhet som analyseres. Kunnskapen som bringes til torgs bør kunne være av interesse for alle som ønsker å forstå og reflektere over alternativer til monopol på ordensmakt i en stat der de offentlige oppgavene vokser i omfang og detaljeringsgrad.

Boken er inndelt i fem deler som gir fremstillingen en ryddig og logisk struktur. Hvordan forfatteren nærmere behandler forholdet mellom politiet og den private sikkerhetsbransjen i den fem-delte strukturen skal belyses i det følgende.

Et utgangspunkt i introduksjonsdelen er at politiet er den dominerende leverandør av nasjonal trygghet, sikkerhet, fred og orden i Danmark og at politiet i en årrekke har vært i konstant vekst som organisasjon. Det dokumenteres også at den private sikkerhetsbransjen har vokst, men på langt 
nær i samme omfang som veksten i politiet og i mindre grad i Danmark enn BOGANMELDELSE i mange andre vestlige land.

En sentral premiss er at politiet og den private sikkerhetsbransjen ikke er motsetninger (s. 21). Forfatteren vil ha leseren til å se at det private og offentlige ikke er virksomheter som utvikler seg på bekostning av hverandre, men er aktører med overlappende oppdrag i parallell vekst (s. 38). Politiet og den private sikkerhetsbransjen kan dermed betraktes som et helhetlig og sammenhengende borgervern, og det er behov for begge typer virksomhet. Det blir fremsatt en tese (på s. 46) om at mange av endringene i politiets formål og oppgaver handler mer om forskyvninger i samfunnet enn om et helt nytt politiparadigme og veksten i den private sikkerhetsbransjen. Det kan være grunn til å se tesen i lys av at forskningsprosjektet boken bygger på er samfinansiert av SikkerhedsBranchen og Københavns Universitet. Forfatteren redegjør på en ryddig måte for finansieringsgrunnlaget (på s. 52-53) og har en reflektert og kritisk distanse til forskningsobjektet i fremstillingen.

Metodisk tar boken et utgangspunkt i kriminologen Paul Ponsaers fire policing-modeller. Dette omfatter foruten de to tradisjonelle og myndighetsorienterte Military Bureaucratic Model og Lawful Policing Model også en mer moderne Community Oriented Policing Model og en postmoderne Public/ Private Divide Policing Model. Forfatteren legger opp til å benytte modellene til å belyse underliggende forestillinger bak politiske utsagn om hva politiets formål og oppgaver er (s. 30). I fremstillingen tjener modellene likevel oftere som en oppsummerende merkelapp på utviklingstrekk forfatteren har fått frem på annen måte enn som et egentlig analyseverktøy. For den som leser boken med et praktisk formål for øye, kan bruken av disse og andre modeller dermed virke mer tyngende enn opplysende for spørsmålet om hvorvidt politimyndighet kan delegeres til private aktører.

Boken bygger også på empiriske forskningsmetoder. Forfatteren har observert politiets virksomhet ved feltarbeid på vakter og ved intervju av 11 ansatte i Københavns Vestegns Politikreds som er en av de største i Danmark. Kunnskapsgrunnlaget om den private sikkerhetsbransjen bygger i større omfang på intervjuer. Det er gjennomført 38 intervjuer med private sikkerhetsaktører fra 12 ulike firmaer eller organisasjoner. De empiriske studiene gir verdifull innsikt i en rekke typer praktiske utfordringer knyttet til ulike løsningsalternativer for fordeling av oppgaver mellom politiet og den private sikkerhetsbransjen.

I metodekapitlet introduseres videre begrepet «kerneopgave» til forskjell fra andre oppgaver politiet kan ha. Forfatteren lener seg på ledelsesteori som definerer organisasjoners kjerneoppgave som «en overordnet abstrakt opgave - hele organisationens raison d'être - og ikke konkrete arbejdsopgaver» (s. 58). Det blir også presisert at for en offentlig virksomhet handler det om «rollen i samfundet» (s. 60). Det diskursanalytiske poenget om at språklige begreper kan gi et handlingsrom for omfordeling av oppgaver kunne gjerne 
vært eksplisitt forklart. I stedet blir det hengende litt i løse luften hvilken BOGANMELDELSE funksjon uttrykket «kerneopgave» skal ha i fremstillingen.

Andre del av boken tar for seg politiets virksomhet i fire kapitler (4-7). Først drøftes definisjonen av politiets samfunnsrolle som en aktør med fysisk maktmonopol, særlig sammenliknet med militærets rolle. Med støtte i sosiologen Jean-Paul Brodeur peker forfatteren på at makten er statens monopol, ikke politiets. Staten kan dermed bestemme hvem som skal ha adgang til bruk av makt, og forfatteren understreker at makt bare er et middel til å løse oppgaver (s. 91). Det avgjørende for hvem som skal ha dette midlet må være hvem som skal utføre hvilke oppgaver. Det blir derfor viktig å avklare hvilke oppgaver politiet skal ivareta, men dette er ikke så enkelt. Forfatteren ser nærmere på hvordan politiloven definerer politiets formål og oppgaver, men finner her liten veiledning til hva politiet ikke skal gjøre og som kan bidra til å avgrense politiets oppgaver.

Forfatteren foretar deretter en analyse av hvordan politiets kjerneoppgaver nærmere har vært definert i styringsdokumenter fra Rigspolitichefen og i politiske dokumenter om reform av politiets oppgaver. Her treffer den tradisjonelle «militære-byråkratiske» og «The lawful policing model» best som forklaringsmodell. Dokumentene som blir analysert er fra tidsperioden 1998-2019. Det konkluderes med at dokumentene ikke bringer noen større klarhet i hvorvidt for eksempel bevoktning er en politioppgave eller ikke (s. 136). Kritikken synes å være at det altomfattende ansvaret loven legger til politiet gir for liten veiledning til hvordan oppgaver skal prioriteres - og for liten veiledning til hva som eventuelt kan delegeres til andre.

Til slutt i andre del behandles politiets selvforståelse. Feltarbeidet forfatteren har gjennomført kommer her til nytte. Ikke overraskende er det her en «community oriented» politimodell, med fokus på service og problemløsning overfor hr. og fru Danmark, som er mest treffende. Forfatteren kaster lys over det praktiske politiliv og fremhever at det er diskrepans mellom praksis og ideologi. Forfatteren kritiserer den overordnede styringen av politiet for å gi mangelfulle signaler om hvilke oppgaver som skal prioriteres. Et poeng som trekkes frem er at verken politikere, ledere eller politifolk synes å oppfatte bevoktning og grensekontroll som eksklusive politioppgaver. Likevel legger disse oppgavene i praksis beslag på betydelige politiressurser. Dermed legger forfatteren til rette for at privat vaktvirksomhet kan utfylle og avhjelpe politiarbeidet og dette danner bro til neste del av boken.

Tredje del av boken tar for seg privat vaktvirksomhet i fire kapitler (8-11). Her gis det innledningvis en kort historisk gjennomgang om sikkerhetsbransjens etablering i Danmark fra Kjøbenhavn-Frederiksberg Nattevagt i 1901 til ISS-Securitas og vedtagelsen av vagtvirksomhedsloven i 1986. Deretter analyseres vagtvirksomhedsloven for å avklare hvordan denne loven legitimerer sikkerhetsbransjen som et supplement til offentlig politiarbeid. Her konstateres det at formålet med loven i utgangspunktet var å sikre at private sikkerhetsfirma gjennomfører virksomheten på en måte som er betryggende 
og forsvarlig for samfunnet, det vil si å rense markedet for useriøse aktører. Samtidig vises det til forarbeidsuttalelser som klart gir uttrykk for at den private sikkerhetsbransjen kan ha en positiv komplementær funksjon til politiet med hensyn til å forebygge kriminalitet.

Videre analyserer forfatteren privat vaktvirksomhet i praksis både innenfor og utenfor vagtvirksomhedsloven og kan her trekke veksler på intervjuarbeidet hun har gjennomført. Tradisjonelt har bransjen særlig vært orientert mot forebygging av og sikring mot brann og tyveri. Forfatteren viser at oppgaveporteføljen i dag spenner vidt og at private vakter står for verditransport, bistår psykiatrien, sikrer ambassader, kjøpesentre, ministerier, flyplasser, utesteder, eventer, sørger for crowd control og mye mer. Det argumenteres overbevisende for at vagtvirksomhedsloven ikke er dekkende for sikkerhetsbransjens virkeområde og at lovens avgrensninger er utdaterte. Et eksempel er at loven ikke gjelder for vaktvirksomhet i det offentlige rom. På Strøget i København har det i mange år vært den private sikkerhetsbransjen som har opprettholdt den offentlige trygghet, sikkerhet, fred og orden. Et annet eksempel er at det er for lett for useriøse aktører å definere seg ut av lovens virkeområde ved å kalle seg noe annet enn sikkerhetsvakt (s. 244). Når politiet heller ikke prioriterer håndhevelse av loven, blir den utilstrekkelig som verktøy til å rense markedet for de useriøse aktørene.

Forfatteren lykkes i del tre godt med å vise at moderne vaktvirksomhet $\mathrm{i}$ stor grad løser nye behov for sikkerhet. Det vil si at det ikke dreier seg om å overta politioppgaver, men om å komplementere dem. Forfatteren peker på at den private sikkerhetsbransjen på mange måter befinner seg i samme situasjon som politiet ved at lovens oppgavebeskrivelse ikke er dekkende for de utfordringer private aktører møter i det praktiske liv.

Fjerde del av boken drøfter samspillet mellom politi og privat vaktvirksomhet i tre kapitler (12-14). Her stilles det spørsmål ved hvem vagtvirksomhedsloven burde omfatte og hvordan relasjonen mellom politiet og den private sikkerhetsbransjen nærmere bør være. Det er utarbeidet tabeller og figurer som gir god pedagogisk oversikt over særtrekk ved politiet og den private sikkerhetsbransjen og som illustrerer hvordan oppgavene overlapper hverandre.

Videre blir det oppstilt to aktuelle idealtypiske modeller for relasjonen mellom offentlig og privat politiarbeid. Den socialliberale modellen, som anses som dekkende for den dominerende ideologien i Danmark, bygger på at det ikke er noen relasjon mellom politiet og den private sikkerhetsbransjen. Politiets ansvarsområde er begrenset og privat vaktvirksomhet er legitimt på privat område. Den neoliberalistiske modellen bygger derimot på at også politimyndighet kan delegeres ut fra en markedstankegang. Sverige blir benyttet som eksempel på denne modellen. Forfatteren advarer mot å gå for langt i denne retning. Det blir eksempelvis pekt på at oppgaver som innebærer maktbruk (og våpen) bør være forbeholdt politiet. 
Mellom den sosialliberale og den neoliberale modellen finner forfatteren BOGANMELDELSE rom for en tredje modell bygget på ikke-økonomisk samarbeid. Det vi si at politioppgaver ikke blir delegert mot økonomiske motytelser. I stedet blir det etablert et strategisk samarbeid, nærmest som en form for partnerskap. Det blir vist til gode erfaringer fra Norge og fra Københavns Vestegns Politikrets med en slik form for formalisert samarbeid. Selv om også denne modellen har utfordringer, ikke minst når det gjelder kulturforskjeller i offentlig og privat sektor, er forfatteren positiv til å videreutvikle denne relasjonsformen. Hun anbefaler i alle fall at virkeområdet for vagtvirksomhedsloven blir utvidet og klargjort (s. 306).

Femte del trekker sammen de ulike trådene i boken et konkluderende kapittel (15). Spørsmålet om hva som egentlig skal være politioppgaver blir betraktet med Ponsaers modeller som prisme. Forfatteren tar ikke standpunkt til hvor grensen for komplementær bruk av den private sikkerhetsbransjen skal trekkes, men inviterer og oppfordrer til en politisk debatt om dette. Avslutningsvis tas det utvetydig til orde for «en helt ny og tydelig vagtvirksomhedslov, der tjener borgernes retssikkerhed og ret til sikkerhed» (s. 322).

Boken behandler et praktisk viktig og prinsipielt interessant emne. Spørsmålet om delegasjon av politimyndighet rører ved helt grunnleggende rettsstatlige problemstillinger om hvordan staten skal trygge og sikre sine borgere. Forfatteren utviser stor praktisk forståelse for hvordan oppgavene med å ivareta trygghet, sikkerhet, fred og orden i samfunnet kan og bør løses. Det er særlig forfatterens praktiske blikk som gjør boken lesverdig. Løsningene som skisseres er pragmatiske og egnet til å gi veiledning om politiske handlingsvalg: «Det må være statens opgave at regulere og kontrollere sikkerhedsområdet til gavn først og fremmest for samfundet og borgeren, og ikke nødvendigvis for at pleje hverken politiets eller erhvervslivets interesser» (s. 262). Forhåpentligvis når det klare konkluderende budskapet om behovet for reform av vagtvirksomhedsloven frem til både Justisministeriet og til Folketinget. Andre som av ulike grunner er interessert i hvilken rolle private aktører kan ha med hensyn til å opprettholde trygghet, sikkerhet, fred og orden i samfunnet vil også ha stor glede av å lese boken.

Ragna Aarli, professor i rettsvitenskap, Juridisk fakultet, Universitetet i Bergen, Norge 